\begin{abstract}
Iranica
Abstracta Iranica Revue bibliographique pour le domaine irano-aryen

Volume 32-33 | 2013

Comptes rendus des publications de 2009-2010
\end{abstract}

\title{
Massoud Azarnoush. Hājīābād and the Dialogue of Civilizations
}

\section{Rémy Boucharlat}

\section{(2) OpenEdition}

1 Journals

\section{Édition électronique}

URL : http://journals.openedition.org/abstractairanica/40456

DOI : 10.4000/abstractairanica.40456

ISSN : 1961-960X

Éditeur :

CNRS (UMR 7528 Mondes iraniens et indiens), Éditions de l'IFRI

\section{Édition imprimée}

Date de publication : 1 décembre 2013

ISSN : 0240-8910

\section{Référence électronique}

Rémy Boucharlat, "Massoud Azarnoush. Hājīābād and the Dialogue of Civilizations », Abstracta Iranica [En ligne], Volume 32-33 | 2013, document 138, mis en ligne le 01 juillet 2016, consulté le 03 octobre 2020. URL : http://journals.openedition.org/abstractairanica/40456 ; DOI : https://doi.org/10.4000/ abstractairanica. 40456

Ce document a été généré automatiquement le 3 octobre 2020.

Tous droits réservés 


\title{
Massoud Azarnoush. Hājīābād and the Dialogue of Civilizations
}

\author{
Rémy Boucharlat
}

\section{RÉFÉRENCE}

Massoud Azarnoush. " Hājīābād and the Dialogue of Civilizations », in : S. M. R. Darbandi and A. Zournatzi, eds., Ancient Greece and Ancient Iran. Cross-Cultural Encounters, Athens, $1^{\text {st }}$ International Conference (11-13 november 2006). Athens, National Hellenic Research Foundation - Cultural Center of the Embassy of the Islamic Republic of Iran Hellenic National Commission for UNESCO, 2008, pp. 41-52.

1 L'A. extrait les documents de sa démonstration des riches découvertes faites sur le site qu'il a fouillé en urgence en 1977 et soigneusement publié en 1994 (cf. Abs. Ir. 17-19, c.r. $\left.n^{\circ} 229\right)$. Ce sont des exemples de la décoration murale, en stuc principalement, basreliefs et sculpture, mais aussi des fragments peints, ainsi que des figurines. Les éléments hellénisants, ou plus largement méditerranéens, sont parfois appliqués tel quel, mais plus souvent réinterprétés. Les uns sont sans doute des importations de l'époque (IV ${ }^{\mathrm{e}}$ s. ap.

J.-C.), mais d'autres avaient été intégrés dans l'art de la Mésopotamie bien avant, aux époques séleucide et parthe, sans doute aussi sur le plateau iranien, mais la documentation manque; ces éléments étaient encore vivaces lors de l'édification du complexe de Ḥājīābād. 


\section{AUTEURS}

RÉMY BOUCHARLAT

CNRS, Lyon 